\title{
Multi-stage Hydrothermal Alteration of Chromium Spinels from the Sabzevar Ophiolite (SE Iran)
}

\author{
ALIREZA ESLAMI ${ }^{1,2}$, BENJAMIN MALVOISIN $^{3}$, \\ FABRICE BRUNET $^{4}$, ALI KANANIAN ${ }^{5}$, WOLFGANG \\ BACH $^{6}$, GIOVANNI GRIECO ${ }^{7}$, ALESSANDRO CAVALLO $^{8}$ \\ AND DIEGO GATTA ${ }^{7}$ \\ ${ }^{1}$ ISTerre Grenoble \\ ${ }^{2}$ University of Grenoble Alpes \\ ${ }^{3}$ ISTerre \\ ${ }^{4}$ Université Grenoble Alpes \\ ${ }^{5}$ University of Tehran \\ ${ }^{6}$ University of Bremen \\ ${ }^{7}$ Università degli Studi di Milano \\ ${ }^{8}$ Università di Milano-Bicocca \\ Presenting Author: alireza.eslami@univ-grenoble-alpes.fr
}

Magnetite deposits comprise a discontinuous trail of massive magnetite ore bodies in highly sheared serpentinites of the Late Cretaceous Sabzevar ophiolitic belt, northeastern of Iran. Spinel grains are observed within both magnetite ores and host serpentinite. Magmatic chromian spinels with compositions close to $\left(\mathrm{Mg}_{0.6}, \mathrm{Fe}_{0.4}\right)\left(\mathrm{Cr}_{1.2}, \mathrm{Al}_{0.75}, \mathrm{Fe}^{3+}{ }_{0.05}\right) \mathrm{O}_{4}$ are preserved as relics in the host serpentinite. They display a porous alteration rim composed of patches of Cr-chlorite, a spinel of composition $\left(\mathrm{Fe}_{0.6}, \mathrm{Mg}_{0.4}\right)\left(\mathrm{Cr}_{1.4}, \mathrm{Al}_{0.4}, \mathrm{Fe}^{3+}{ }_{0.2}\right) \mathrm{O}_{4}$ (Cr-spinel II), magnetite and ferritchromite $\left(\mathrm{FeCr}_{2} \mathrm{O}_{4}\right)$. In the magnetite ore bodies, $\mathrm{Cr}$-spinel II is surrounded by ferritchromite and magnetite. Two generations of magnetite are discernible. A first $\sim 20 \mu \mathrm{m}$-wide magnetite rim displays a $\mathrm{SiO}_{2}$ content $<1$ wt.\%. A second magnetite rim is larger (40 to $200 \mu \mathrm{m}$ ) and shows a higher $\mathrm{SiO}_{2}$ content, ranging between 1.21 and 2.35 wt.\%. A micrometer ferritchromite rim between $\mathrm{Cr}$-spinel II and magnetite I was identified with TEM. Thermodynamic modeling indicates that Cr-spinel II and chlorite are first produced after magmatic spinel between 575 and $725{ }^{\circ} \mathrm{C}$. Ferritchromite and magnetite are predicted to form at lower temperature $\left(\mathrm{T}<400^{\circ} \mathrm{C}\right)$ under a high $\mathrm{H}_{2}$ fugacity, probably associated with serpentinization. We interpret this progressive alteration as the result of seaweater/mantle rock interaction during exhumation on the seafloor. Thermodynamic calculations also suggest that the magnetite ore is formed through $\mathrm{Fe}$ rather than $\mathrm{Cr}$ transfer. Iron has to be transported at a scale $>10 \mathrm{~m}$ to explain magnetite ore formation during serpentinization. 